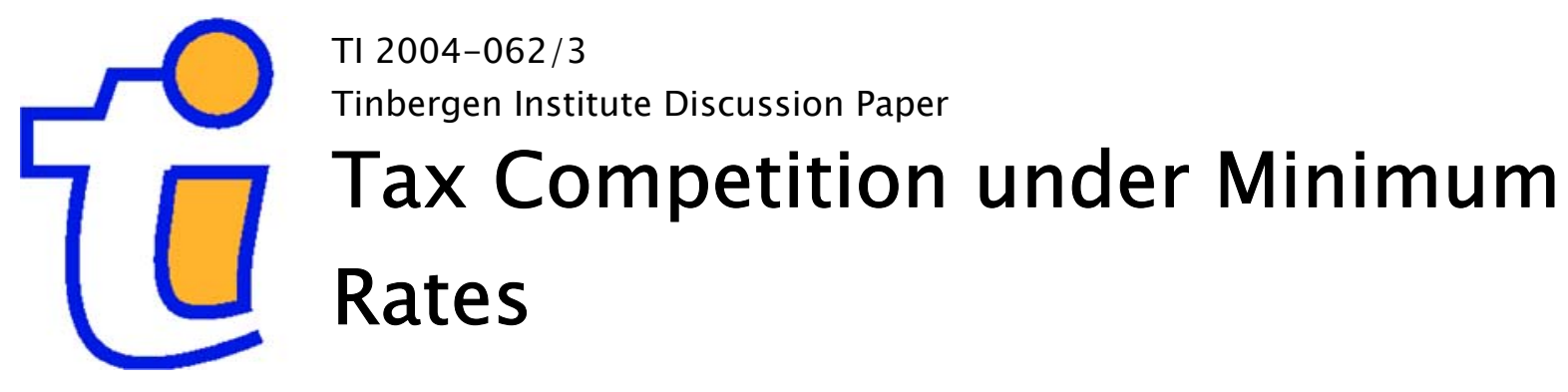

Michiel Evers'

Ruud A. de Mooijl, 2, 3, 4

Herman R.J. Vollebergh'

' Faculty of Economics, Erasmus Universiteit Rotterdam,

2 Tinbergen Institute,

${ }^{3} C P B$,

${ }^{4}$ CESifo. 


\section{Tinbergen Institute}

The Tinbergen Institute is the institute for economic research of the Erasmus Universiteit Rotterdam, Universiteit van Amsterdam, and Vrije Universiteit Amsterdam.

Tinbergen Institute Amsterdam

Roetersstraat 31

1018 WB Amsterdam

The Netherlands

Tel.: $\quad+31(0) 205513500$

Fax: $\quad+31(0) 205513555$

Tinbergen Institute Rotterdam

Burg. Oudlaan 50

3062 PA Rotterdam

The Netherlands

Tel.: $\quad+31(0) 104088900$

Fax: $\quad+31(0) 104089031$

Please send questions and/or remarks of nonscientific nature to driessen@tinbergen.nl.

Most TI discussion papers can be downloaded at http://www.tinbergen.nl. 


\title{
Tax Competition under Minimum Rates: The Case of European Diesel Excises*
}

\author{
Michiel Evers \\ Erasmus University Rotterdam \\ Ruud A. de Mooij** \\ Erasmus University Rotterdam \\ Tinbergen Institute, $C P B$ and CESifo \\ Herman R.J. Vollebergh \\ Erasmus University Rotterdam
}

June 2004

\begin{abstract}
This paper estimates Nash-type fiscal reaction functions for European governments competing for revenue from diesel excises. It appears that European governments strategically set their excise levels by responding to their neighbors' tax rates. This provides evidence for the presence of tax competition in diesel excises. In fact, a $10 \%$ higher rate in neighboring countries (in terms of the user price) induces a country to raise its own rate by between 2 and 3\%. This impact is robust for alternative specifications. By imposing restrictions on excise levels, EU harmonization of excises in 1987 and the introduction of a minimum in 1992 exerted a positive impact on the excise level in a number of EU countries. It has not, however, significantly reduced the intensity of tax competition. Indeed, strategic tax responses have not significantly been reduced by these harmonization policies. We also find that high-tax countries appear to compete more aggressively than low-tax countries in the sense that they feature larger strategic tax responses. There is no significant difference between large and small countries.
\end{abstract}

JEL Codes: H23, H77, H87, R4

Key words: Diesel excise; Strategic tax setting; Minimum rates; European Union.

\footnotetext{
${ }^{*}$ We are grateful to Marko Runkel and Bas Jacobs for helpful suggestions.

** Corresponding author: Erasmus University Rotterdam, P.O. Box 1738, 3000 DR Rotterdam, The Netherlands. Tel. +31 104081485 . E-mail: demooij@few.eur.nl.
} 


\section{Introduction}

European governments face an increasing international mobility of tax bases. For instance, differences in excise rates on beverages or cigarettes in Europe induce incentives for cross-border shopping (Cnossen, 2002). Similarly, corporate tax rate differentials are found to exert an impact on the location of foreign direct investment; an effect that tends to be increasing over time (De Mooij and Ederveen, 2003). As a response to this, European governments engage in a process of tax competition, i.e. they strategically set their tax rates in order to lure mobile factors of production or cross-border shoppers. Strategic tax setting means that, by reducing tax rates, governments aim to broaden their own tax base, thereby recovering or even raising fiscal revenue. Moreover, enlarging a tax base may also raise welfare of domestic inhabitants if it is accompanied by additional benefits, such as productivity gains.

The theory of tax competition reveals, however, that strategic tax setting is typically inefficient from a European perspective. ${ }^{1}$ Indeed, independent governments do not take account the welfare implications of their own actions on neighboring countries when deciding about their own tax rates. Thus, they end up in a prisoner's dilemma in which fiscal externalities cause inefficiently low levels of public goods supply. Tax harmonization, perhaps through minimum rates, can therefore be welfare improving.

Empirical studies on tax competition usually explore whether tax rates are decreasing over time in light of the increasing economic integration among countries. For instance, Devereux et al (2002a) show that the mean corporate tax rate in 16 OECD countries has gradually declined between 1982 and 2001. This holds both for statutory rates and average effective tax rates and provides an indication that tax competition is indeed an important phenomenon in the OECD.

Recently, a number of studies have tried to empirically assess the importance of tax competition between countries in an alternative way. In particular, these studies estimate so-called fiscal reaction functions. These measure the responsiveness of a countries' tax rate to the rate of neighboring countries, thereby controlling for other determinants of the tax rate. Most of these studies focus on corporate taxation (Besley

\footnotetext{
${ }^{1}$ See Wilson (1999) or Zodrow (2003) for recent reviews of the literature on tax competition.
} 
et al., 2001; Devereux et al., 2002b; Altshuler and Goodspeed, 2002). ${ }^{2}$ They typically show that countries in the OECD and Europe do indeed systematically respond to each other's corporate tax rates. For instance, Devereux et al. (2002b) find that strategic tax responses are strong and highly robust for both statutory tax rates and (marginal and average) effective tax rates in 16 OECD countries. For the European Union, Altshuler and Goodspeed (2002) find similar results for alternative specifications for the tax game, i.e. Nash and Stackelberg. Their results suggest that a $10 \%$-point higher tax rate in neighboring countries implies an $8 \%$ higher rate in a particular European country. These findings provide evidence for the claim that governments aggressively compete with their corporate tax systems for foreign direct investment. ${ }^{3}$ In a recent study, Devereux et al. (2004) estimate fiscal reaction functions for US States competing for revenue from excises on cigarettes and gasoline. They explore both vertical tax competition between States and the federal government, and horizontal tax competition among States. For excises on cigarettes, they find that horizontal tax competition is important: a one-cent increase in the neighbor state excise level induces a rise in the home tax rate of 0.5 cents. For gasoline, they report mixed findings: the strategic interactions are not always statistically significant.

This paper empirically explores whether tax competition in Europe is also important for a different tax, namely the excise on commercial diesel. Differences in excise duties between European countries have a potentially important impact on the fuelling behavior of transport companies. Indeed, most trucks can cover between 1500 and 3000 kilometers on a single tank. As excise duties account for between 10 to 12 percent of the running cost of road haulage companies, active fiscal planning of international transport routes can substantially save on production costs. As a response, European governments may strategically set their diesel excise rates so as to attract trucks to fuel in their country and thus maximize the fiscal revenue from their excise duties.

Analyzing tax competition in diesel excises is particularly interesting for at least four reasons. First, trucks are highly mobile so that fueling behavior is elastic in

\footnotetext{
${ }^{2}$ There is a substantial emprical literature that estimates fiscal reaction functions for local governments as well, see Bruckner (2002) for an overview.

${ }^{3}$ A related literature explores how jurisdictions strategically determine their stringency of environmental regulations. In response to regulations in neighbouring jurisdictions, they may thus reduce this stringency in order to attract foreign direct investment, see Levinson (2003) for an overview.
} 
demand, at least for an individual European country. Hence, one might expect that tax competition is especially intense in the field of diesel excises. Second, the European Union has imposed a minimum excise rate on diesel in 1992. Inspired by the Treaty of Rome (Article 99(old)), the EU first introduced a proposal (Com(87)327) for harmonizing mineral oil excises in 1987. This proposal has subsequently been modified into a policy of minimum excise rates. These harmonization efforts seem to have affected the excise levels. Indeed, we observe a rising trend in the diesel excise in Europe during the last 20 years, but especially during the harmonization period of the late 1980s (see section 3 for further details). Hence, it may seem that the minimum excise level has significantly reduced the intensity of tax competition in European diesel excises. The question is, however, whether these tax harmonization efforts have also affected the strategic tax interactions between countries, i.e. the other way of measuring the intensity of tax competition. A third reason why diesel excises are interesting is that, contrary to differences in effective corporate tax rates, differences in diesel excises are less likely to create distortions in the international allocation of real capital. Hence, tax competition is due to international tax arbitrage, rather than a reallocation of production. In this respect, tax competition with diesel excises is reminiscent to tax competition in statutory corporate tax rates (which is important for profit shifting within multinational companies) or other indirect taxes such as VAT and other excises (determining the incentives for cross-border shopping), which also involve a form of international tax arbitrage. ${ }^{4}$ A final reason why tax competition in diesel excises is interesting to explore is that it involves a specific tax, rather than an ad-valorem tax (which is the case with corporate taxes or VAT). As specific taxes tend to fall over time in real terms due to inflation, countries regularly upgrade their excise rates, either on a discretionary basis or by means of indexation. This implies substantial variation in excise levels over time.

In estimating our Nash-type fiscal reaction functions for diesel excises, this paper exploits a panel of 17 European countries between 1978 and 2001. Apart from exploring the magnitude of the strategic tax interactions, these data allow us to examine three other propositions that play a role in the debate on tax competition.

\footnotetext{
${ }^{4}$ Note that one of the concerns of the European Commission is that trucks and buses make a detour to make use of cheaper fuel, thereby exacerbating environmental problems in Europe. Together with the fear for aggressive tax competition, this has lead to a proposal for a harmonized excise duty on commercial diesel fuel, to be introduced in 2010, see COM (2002)410 final. This is to replace the current minimum excise rate.
} 
First, we consider how strategic tax setting between countries is influenced by coordination efforts of the European Union. In particular, as our data cover both the pre-harmonization period and the post-harmonization period, we can test how the imposition of a minimum excise rate has actually changed the strategic tax setting among countries. Second, we explore whether country size matters for tax competition. The literature has shown that country size indeed matters for the level of tax that countries set in a tax competition game (Bucovetski, 1991; Kanbur and Keen, 1993). We empirically explore whether it also matters for their responsiveness to other countries' tax rates. Finally, following Devereux et al. (2002b), we analyze whether the magnitude of the initial excise rate matters for the strategic tax response of a country. In particular, Devereux et al. (2002b) find that countries featuring a relatively high tax rate respond more strongly to tax changes in neighboring countries.

The rest of this paper is organized as follows. Section 2 develops a model to understand the strategic tax interactions of diesel excises. It also discusses how a minimum tax rate affects the outcome of the Nash game. Section 3 describes the data and the empirical specification of the model. Section 4 reports the empirical results. Finally, section 5 concludes.

\section{Theoretical model}

We develop a partial equilibrium model, describing two countries and a single taxed good called diesel. Superscript $h$ refers to the home country and superscript $f$ refers to the foreign country. We assume that both countries host a transport sector that exerts demand for diesel. The size of the transport sector in the two countries may differ. In particular, the home country hosts $H$ transport companies, while in the foreign country there are $F$ such firms. Note that size here does not refer to ownership, but rather to the amount of goods transported through a country, e.g. the amount of kilometers driven by trucks within the borders of a country.

The price of diesel, $p$, is determined on competitive world markets. A large number of identical transport firms in each of the two countries are unable to affect this market price. In fact, we take the aggregate world demand for diesel as fixed. The government in both countries levies an excise on diesel, described by respectively $\tau^{h}$ and $\tau^{f}$. The tax rates are set independently in a Nash-setting. The excise is a specific tax levied on each unit of diesel, i.e. independent of price. We assume that the origin 
principle applies in the sense that transport companies pay the excise duty at the place where diesel is actually bought.

\section{Fueling behavior of transport firms}

Firms in the transport sector buy diesel either in their home country or abroad, e.g. while transporting goods to a foreign location. In their home country, they pay a price inclusive of tax equal to $p+\tau^{h}$. Buying diesel in the foreign country goes at a price $p$

$+\tau^{f}$. If the tax rates in the two countries would be equal, truck drivers would be indifferent between fueling at home or abroad. In that case, the average number of litres diesel used in a country (i.e. our measure of the size of the transport sector), will be more or less equal to the number of litres fueled. In the presence of different excise rates this will no longer be the case. For some companies, exploiting the opportunities for international tax arbitrage goes without cost. Hence, they will fuel in the low-tax country if possible, even with small tax rate differentials. For other companies, there may be some costs involved in fueling in the low-tax country, e.g. because they have to make a detour, the surface of their home country is large, or they fuel more often. Therefore, we introduce a cost of fueling in a foreign country, $c_{i}^{h} \varepsilon\left[0, \beta^{h}\right]$. This cost differs across firms. Subscript $i$ is used to refer to a particular transport firm. As long as the home country is the low-tax country, i.e. $\tau^{h}<\tau^{f}$, firms in the home country will always decide to fuel at home. If the home country is the high-tax country, i.e. $\tau^{h}>\tau^{f}$, then transport company $i$ minimizes its costs when fueling in the foreign country if and only if the following condition holds:

$p+\tau^{h}>p+\tau^{f}+c_{i}^{h}$

or, equivalently:

$\tau^{h}-\tau^{f}>c_{i}^{h}$

Hence, firms fuel abroad if the gains of lower tax payments exceed the additional costs of fueling abroad. If condition ( $\left.1^{\prime}\right)$ does not hold, a company will fuel in the home country. 
We assume that the heterogeneous cost of fueling diesel abroad, $c_{i}{ }^{h}$, follows a continuous cumulative density function $G^{h}\left(c_{i}^{h}\right)$. For each tax differential, there thus exists a value $c^{h^{*}}$, at which a firm is indifferent between fueling in the home country or fueling in the foreign country, i.e. $\tau^{h}-\tau^{f}=c^{h^{*}}$. All domestic firms featuring a higher value $c_{i}^{h}>c^{h^{*}}$ will fuel in the home country, while all firms featuring $c_{i}^{h}<c^{h^{*}}$ will fuel in the foreign country. The fraction of firms that will fuel in the foreign country is therefore equal to $G^{h}\left(c^{h^{*}}\right)$, while the corresponding density at this point is $g^{h}\left(c^{h^{*}}\right)$. For transport companies in the foreign country, a similar story applies in the case $\tau^{h}<\tau^{f}$.

\section{Revenue maximization by governments}

We assume that each government behaves in a Nash manner. It chooses its own tax rate to maximize its revenue, while taking the tax rate of the other country as given. Tax revenue in the home country $R\left(\tau^{h}, \tau^{f}\right)$ is given by:

$$
\begin{aligned}
R\left(\tau^{h}, \tau^{f}\right) & =\tau^{h} H\left[1-G^{h}\left(\tau^{h}-\tau^{f}\right)\right] & & \text { if } \tau^{h}>\tau^{f} \\
& =\tau^{h} H+\tau^{h} F G^{f}\left(\tau^{f}-\tau^{h}\right) & & \text { if } \tau^{h}<\tau^{f}
\end{aligned}
$$

Expression (2) reveals that, as long as the tax rate exceeds the rate in the foreign country, $\tau^{h}>\tau^{f}$, some domestic transport companies will fuel abroad, thereby eroding the tax base in the home country. If the home country features a lower tax rate than its neighbor, $\tau^{h}<\tau^{f}$, some trucks from the foreign country will decide to fuel in the home country, thereby broadening the tax base in the home country and raising extra tax revenue.

Maximizing (2) yields the following best response of the home country's tax rate for a given rate in the foreign country:

$$
\begin{array}{rlrl}
\tau^{h}\left(\tau^{f}\right) & =\left[1-G^{h}\left(c^{h^{*}}\right)\right] / g^{h}\left(c^{h^{*}}\right)=R\left(\tau^{h}, \tau^{f}\right) / \tau^{h} H g^{h}\left(c^{h^{*}}\right) & & \text { if } \tau^{h}>\tau^{f} \\
& =\left[H / F+G^{f}\left(c^{f^{*}}\right)\right] / g^{f}\left(c^{f^{*}}\right)=R\left(\tau^{h}, \tau^{f}\right) / \tau^{h} F g^{f}\left(c^{f^{*}}\right) & \text { if } \tau^{h}<\tau^{f}
\end{array}
$$

This first-order condition (3) yields the implicit tax reaction function of a general form. It reveals that the optimal tax rate for a home government, given the tax rate in 
the foreign country, is determined by the marginal loss in tax revenue due to a higher rate. If the home country happens to be the high-tax country $\left(\tau^{h}>\tau^{f}\right)$, this impact depends on $\mathrm{Hg}^{h}$ (.) in the denominator of (3), which reflects the marginal reduction in the tax base (i.e. the marginal loss in revenue from diesel fueled at home by domestic transport companies) in response to a higher domestic tax rate. If it is the low-tax country $\left(\tau^{h}<\tau^{f}\right)$ the impact depends similarly on $F g^{f}($.$) , i.e. the marginal loss in$ revenue from diesel fueled at home by foreign companies.

To more clearly illustrate the intuition behind the tax reaction function in (3), let us consider the special case of a uniform distribution for $g^{j}($.$) on the interval \left[0, \beta^{j}\right]$ for $j=h, f$. With such a uniform distribution, we have $G^{j}\left(c^{j}\right)=c^{j} / \beta^{j}$ and $g^{j}\left(c^{j}\right)=1 /$ $\beta^{j}$ for $j=h, f$. The first-order condition for the best response of the home country's tax now reads: ${ }^{5}$

$$
\begin{aligned}
\tau^{h}\left(\tau^{f}\right) & =\quad 1 / 2\left(\tau^{f}+H / F \beta^{f}\right) & & \text { if } \tau^{f}<H / F \beta^{f} \\
& =\quad \tau^{f} & & \text { if } H / F \beta^{f}<\beta^{h} \\
& =\quad 1 / 2\left(\tau^{f}+\beta^{h}\right) & & \text { if } \tau^{f}>\beta^{h}
\end{aligned}
$$

Expression (4) suggests that a higher foreign tax rate will raise the tax rate in the home country if the cost of fueling abroad follows the uniform distribution. With small and large initial foreign tax rates, the response in (4) is exactly $1 / 2$. For the case $H / F \beta^{f}<\beta^{h}$, if it exists at all, the home country sets its tax equal to that in the foreign country.

Assuming that $\beta^{h}=\beta^{f}$, Kanbur and Keen (1993) use (4) to show that small countries will always set their tax rates lower than large countries in the Nash equilibrium. In expression (4), this is reflected in the term $H / F$, which measures the size of the transport sector in the home country, relative to the foreign country. The intuition for this is the following. Suppose that both countries start with the same tax rate. Now the increase in the demand for diesel from a marginal cut in the tax rate depends on the size of the tax base in the other country. For the small country, this tax base is large so that the broadening of the domestic tax base is substantial if it lowers its tax. For the large country, the opposite holds. As a result, the small country will always find it optimal to set its tax rate lower than the large country.

\footnotetext{
${ }^{5}$ The tax reaction function in (4) is a slight generalization of Kanbur and Keen (1993). They derive tax reaction functions for general consumption taxes in the presence of cross-border shopping.
} 
We use the uniform distribution in (4) only to illustrate the intuition behind the tax reaction function. For more general (cumulative) density functions for $c_{i}^{h}$ and $c_{i}^{f}$, expression (3) will take a more general form. In the case of tax arbitrage with respect to commercial diesel use a non-uniform distribution seems more likely. Indeed, a number of trucks can probably choose their location to fuel without costs. This would imply that the distribution function $G^{j}\left(c^{j}\right)$ is skewed to zero. In the empirical section, we propose a more general tax reaction function to estimate how European governments actually respond to each other's diesel excise rates. Thereby, we also explore the impact of country size (i.e. the term $H / F$ ) and the tax gap (i.e. the first or second term in (3)). Before doing so, however, we first explore how the imposition of a minimum excise rate affects the outcome of the Nash game.

\section{The impact of a minimum tax rate}

The EU agreed upon a harmonized excise rate in 1987, which was later modified into a minimum excise rate in 1992. For some low-tax countries, the minimum excise level actually appeared to be binding. How does such a minimum affect the Nashgame between countries?

Suppose that the EU imposes a lower bound $\eta$ on the tax rate of countries $h$ and $f$ in the previous model. This minimum is assumed to be binding for the low-tax country, which we assume is country $f^{6}$ In case of a uniform distribution, Kanbur and Keen (1993) show that, if a Nash equilibrium exists, it must be that:

$\begin{aligned} \tau^{f} & = & \eta \\ \tau^{h} & = & 1 / 2\left(\eta+\beta^{h}\right)\end{aligned}$

Hence, the low-tax country sets its tax rate equal to the minimum level, while the response to this by the high-tax country does not change compared to that in expression (4). Hence, a minimum rate is likely to raise the tax rate in some countries. However, it is not a priori clear that it reduces the strategic tax interactions. In the next section, we include the minimum rate in our regressions and empirically explore whether the minimum affects the fiscal reactions of countries to each other's tax rates

\footnotetext{
${ }^{6}$ If the minimum tax would be non-binding for the low-tax country, the outcome in (3) would be unchanged.
} 
in Europe. Thus, we test the Kanbur-Keen hypothesis reflected in (5) for the case of excises on commercial diesel.

\section{Empirical analysis}

As to the econometric specification of (3), we estimate the following linear fiscal reaction function, where $n$ countries compete in a Nash-setting for fiscal revenue from diesel excises: ${ }^{7}$

$$
\tau_{t}^{i}=\sum \omega^{i} \tau_{t}^{-i} \beta+X_{t}^{i} \theta+d^{i} \varphi+d_{t} \eta+\varepsilon_{t}^{i} \quad i=1, \ldots n
$$

where index $i$ stands for a home country, $-i$ denotes all foreign countries, and $t$ is an index for time. The variable $\tau_{t}^{i}$ is our tax measure, $\omega^{i}$ is a weighting matrix discussed below, $X_{t}^{i}$ is a vector of exogenous control variables, $d^{i}$ are country fixed effects, $d_{t}$ are time fixed effects, and $\varepsilon_{t}^{i}$ is an error term which is assumed to be normally distributed. The parameters $\beta, \varphi, \eta$ and the vector $\theta$ will be estimated. The key coefficient in (6) is the reaction of country $i$ to the tax rates of other countries $-i$, which is reflected by $\beta$.

Equation (6) contains a so called weighting matrix, in which row $i$ is denoted by $\omega^{i}$. It determines which foreign countries' tax rates exert an impact on a particular countries' tax. We explore alternative weighting matrices to check the robustness of the strategic tax responses. In particular, our benchmark is that country $i$ only responds to the tax rate of countries that share a common border. Hence, row $\omega^{i}$ contains a zero if a particular country $-i$ does not share a common border with country $i$, and a positive weight if there is a common border. ${ }^{8}$ The tax rates of neighboring countries that feature a positive weight are equally weighted in $\omega^{i}$, with the weights summing up to one. Subsequently, we analyze a weighting matrix in which all countries within a range of 1000 kilometer feature positive weights, and explore trade shares instead of uniform shares. Before elaborating further on the econometric methodology, we first discuss the data.

\footnotetext{
${ }^{7}$ Compare Devereux et al. (2002b) and Altshuler and Goodspeed (2002).

${ }^{8}$ For the Netherlands-Luxembourg and Italy-Greece, we also impose a positive weight. In the former case, the two countries are small and close to each other while many transport flows from and to the Netherlands pass through Luxemburg. The latter case is a necessary assumption, because otherwise Greece would not have any neighboring country in our weighting matrix. Excluding Greece from our sample, however, hardly influence our results.
} 
For the excise rate on diesel, we use data from a balanced panel of 15 countries of the European Union, plus Norway and Switzerland. The data are taken from the OECD/IEA Energy Prices and Taxes, which provide information about both diesel excise levels and prices for the period 1978-2001. As a measure for the excise rate, we take the ratio of the excise and the price inclusive of excises (but exclusive of VAT). The reason for taking this ratio is that it provides a comparable measure for the excise rate across countries. Moreover, it is not sensitive to exchange rate fluctuations that appeared in the pre-1999 period in the EU. ${ }^{9}$

Figures 3.1 and 3.2 show, respectively, the development of the mean value for the excise ratio between 1978 and 2001, and its coefficient of variation (standard variation across countries divided by the mean). The appendix presents the development of the excise ratio for each of the countries separately. Figure 3.1 reveals that the excise ratio in Europe gradually increased over time. In particular, where excises made up around one quarter of the after-tax diesel price during the late 1970s, this share was more than doubled in the late 1990s. This rise was especially significant between 1985 and 1995. This is exactly the period in which the EU adopted its harmonization policy regarding diesel excises. In particular, in 1987 the European Union implemented its first proposal aimed at harmonizing excise rates. Apparently, countries anticipated this, as we observe that the excise ratios started to rise already in 1985. The harmonized excise rate has been gradually increased between 1987 and 1992, when the harmonized rate was transformed into a minimum rate. $^{10}$

Since 1992, this minimum rate has remained unchanged at a level of $€ 0.245$ per litre. Because the excise involves a specific tax, i.e. per unit of consumption, the real value of this minimum excise rate gradually fell since 1992. This has made the minimum excise less important for the development of the excise ratio in European

\footnotetext{
${ }^{9}$ For the pre-1999 period, the excise rates are expressed in 1999 Euro conversion rates. Hence, exchange rate fluctuations in the pre-1999 period are not captured by the data for excise levels. As they can be important for the real value of the excise levels, we prefer to use the excise ratios rather than excise levels.

${ }^{10}$ Note that, although Norway and Switzerland are not members of the EU, the minimum rate is not binding for them. For Norway, the introduction of the EU minimum was accompanied by a rise in the level of the excise so as to conform with the trend in the rest of Europe.
} 
countries. Indeed, as most countries index their excises rates to inflation or increase them on a discretionary basis, the gap between the actual excise levels and the minimum level has increased after 1992. ${ }^{11}$ In 2000 and 2001, we observe a sharp reduction in the excise ratio in figure 3.1. This is due to an increase in the pre-tax diesel price, which pulls down both the excise ratio and the minimum rate. Overall, the results suggest that the minimum excise rate has significantly reduced the intensity of tax competition, as measured by the development in the level of the excise ratio. ${ }^{12}$ In 2003, the minimum was only binding for Greece, while Luxemburg was only slightly above the minimum rate at $€ 0.253$ per litre.

Figure 3.1: Mean and minimum diesel excise ratio in Europe, 1978-2001

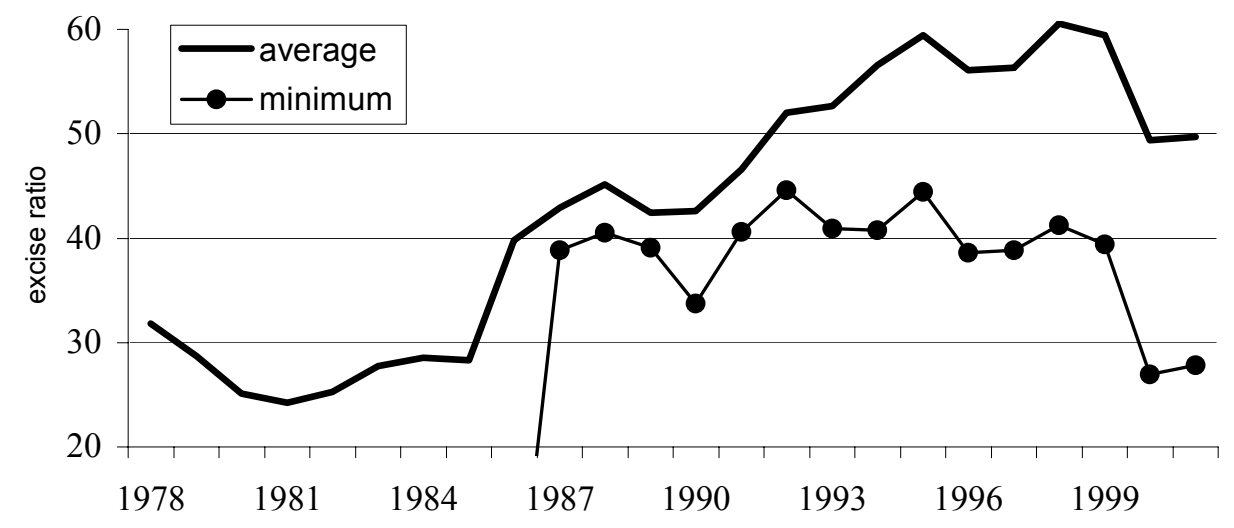

Figure 3.2 shows the development in the spread in excise ratios across European countries. It shows that the gradual increase in the excise ratios between 1978 and 2001 was accompanied by a steady reduction in the variation across countries. Indeed, the period until 1992 shows a process of rapid convergence (sigma convergence): the coefficient of variation dropped from over $60 \%$ in the early 1980 s to around $16 \%$ in 1992. Again, the harmonization efforts of the EU have been responsible for this development. Indeed, the appendix reveals that the minimum excise has been binding for a number of low-tax countries. By raising their excises to conform to the

\footnotetext{
${ }^{11}$ Note that changes in the net of tax diesel price do not affect the difference between the average and the minimum excise ratio.

${ }^{12}$ In a recent proposal, the Finance ministers of the EU agreed upon a proposal for a new Directive on Taxation of Energy Products, originally put forward in COM(1997)30. The aim is to increase the minimum excise duty to $€ 0.33$ per litre by 2012 .
} 
minimum European rate, this triggered the process of convergence. ${ }^{13}$ Yet, we do not observe full convergence: the variation has not entirely disappeared since 1992 and even tends to rise a bit lately.

Figure 3.2: Coefficient of variation of diesel excise ratio, 1978-2001

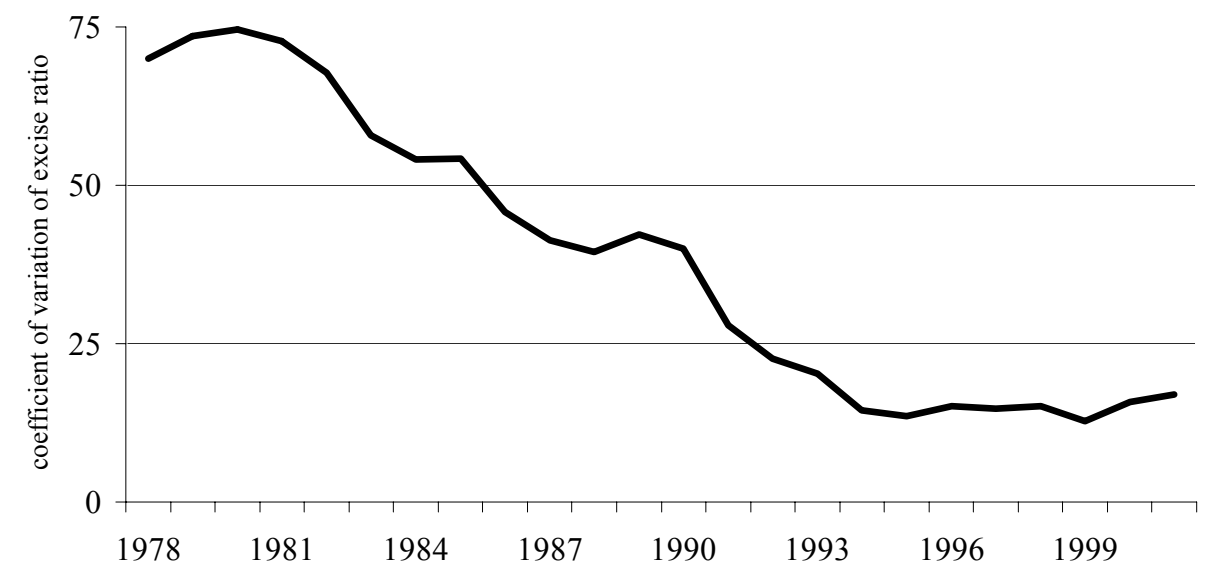

\section{Control variables}

We explicitly control for a number of exogenous variables that affect a countries' tax rate (see table 3.1 for some descriptive statistics) in expression (6). As is clear from (3), the vector of controls should contain a measure for the size of the transport sector in a country. Size here is not determined by ownership of transport companies, but rather by the number of kilometers that trucks drive through a country. As we do not have direct access to this measure, we include two other variables to capture this effect. These are taken from the World Road Statistics Database from the International Road Federation. First, we take the length of motorways (ROAD) as an indicator for country size. In addition to this, we include the number of trucks divided by the number of passenger cars in a country (TRUCKSHARE) to obtain an indicator

\footnotetext{
${ }^{13}$ By testing for $\beta$-convergence, we obtain a coefficient of $\beta=-5.42$ (t-value -15.23 ). Hence, a country featuring an excise rate that deviates from the European mean gradually moves towards this mean. On average, the excise gap is reduced by $5.42 \%$ annually. Computing the speed of $\beta$-convergence in the corporate tax rates of 13 European countries used by Devereux et al. (2002ab), we get $\beta=-1.83$ for the statutory rates ( $t$-value -2.93 ) and $\beta=-2.56$ for the average effective tax rates (t-value -5.89 ). Hence, diesel excises have converged faster in Europe than corporate tax rates which have not been subject to harmonization efforts of the EU.
} 
for the (relative) size of the transport sector. Together, these two variables should provide an appropriate measure for the size of the transport sector of a country.

Diesel excise rates are probably influenced by lobbying behavior of transport companies. To capture this potential impact of the diesel lobby, we use the ratio of diesel consumption to the number of inhabitants of a country (DIESELCAP). ${ }^{14}$

Diesel excises involve specific taxes. Many countries index these excises to prices or adjust them on a discretionary basis in order to avoid a gradual depreciation of its real value. This contrasts with ad-valorem taxes such as VAT or corporate taxes, which are not indexed. If all tax authorities would adjust excises to (local) inflation, the excises are likely to follow a trend. Without correction, this would wrongly be taken as evidence for tax competition (ceteris paribus the diesel price). Therefore, we control for the PRICE index in estimating (6). We also control for the DIESELPRICE, which directly affects the excise ratio. Also the minimum diesel excise rate set by the EU may result in a (spurious) pattern of strategic tax interactions if we do not control for it. Indeed, countries are likely to adapt their tax rates in similar directions in response to the harmonization efforts of the EU (see also section 2). Therefore, we also control for the minimum excise rate $(M I N)$ in our regressions.

Finally, we include fixed effects, $d^{i}$, to control for unobserved heterogeneity between countries. In terms of (3), the fixed effects may reflect the country-specific parameters $\beta^{i}, i=1, \ldots, n$. In addition to this, we include time fixed effects to control for common shocks across countries.

\section{Table 3.1 Descriptive statistics}

\begin{tabular}{lcccc} 
Variable & Mean & Maximum & Minimum & Std. Dev. \\
\hline ROAD & 2.25 & 11.00 & 0.01 & 2.78 \\
TRUCKSHARE & 0.16 & 2.65 & 0.01 & 0.20 \\
DIESELCAP & 0.27 & 1.78 & 0.07 & 0.21 \\
PRICE & 0.79 & 1.31 & 0.06 & 0.26 \\
DIESELPRICE & 0.20 & 0.32 & 0.10 & 0.05 \\
MIN & 0.14 & 0.25 & 0.00 & 0.12
\end{tabular}

\footnotetext{
${ }^{14}$ We also experimented with the share of diesel in total consumption of fuel (gasoline and diesel), without any effect on our main conclusions.
} 


\section{Econometric procedure}

The tax ratios on the left-hand-side of (6) are potentially endogenous. Indeed, if countries play a Nash game, they respond to each other's tax rates, which directly implies an endogeneity problem (Altshuler and Goodspeed, 2002; Brueckner, 2002). To control for this endogeneity, we estimate (6) using two-stage-least-squares. In particular, we estimate an equation with the endogenous regressors from (6) as the dependent variable, i.e. $\omega^{i} \tau_{t}^{-i}$. The exogenous regressors and some additional variables that are independent of $\tau_{t}^{-i}$ in equation (6), are then used as instrument variables. Thus, we first estimate:

$$
\omega^{i} \tau_{t}^{-i}=\beta_{1} \sum \omega^{i} X_{t}^{-i}+\beta_{2} X_{t}^{i} \theta+\beta_{3} d^{i} \varphi+\beta_{4} d_{t} \eta+\varepsilon_{t}^{i}
$$

with $\sum \omega^{i} X_{t}^{-i}$ being the weighted exogenous variables, defined in the same way as the weighted tax rate. In a second step, the fitted values for the endogenous regressor $\omega^{i} \tau_{t}^{-}$ ${ }^{i}$ for each of the countries are inserted into (6), which is then estimated using OLS.

We first estimate a fixed effects model by including a country specific constant $d^{i}$ as in (6). These fixed effects $d^{i}$ eliminate the possible problem of omission of unobserved country characteristics that are fixed over time. We also included time fixed effects, $d_{t}$, to control for common time shocks. Secondly, we estimate (6) in first-differences. The first-differences model captures the reaction of a country to changes in the other countries' tax rates. By removing stochastic trends using two period lags, the first-difference model estimates only short-term relations between the variables. Following Altshuler and Goodspeed (2002), we use two-year intervals to minimize the loss of data and to deal with the lag of political response to changes in the tax ratios of other countries. ${ }^{15}$

In estimating the strategic tax responses in (6), we concentrate on the estimated coefficient for the other countries' tax rate, i.e. $\beta$. This parameter is interpreted as a measure for the intensity of tax competition across European countries. It is not a priori clear that this measure for tax competition is equivalent across countries and across time. Indeed, the intensity of tax competition may be influenced by the introduction of a minimum excise rate, or may differ between large

\footnotetext{
${ }^{15}$ We also explored one and three year lags. This had little impact on the results. Results available on request.
} 
and small countries, or between high-tax and low-tax countries. To analyze whether the intensity of tax competition depends on these variables, we explore how the estimated value for $\beta$ is affected by three variables: (i) the minimum excise in the EU; (ii) country size; and (iii) the size of the tax gap, i.e. the tax ratio of a country relative to the median tax ratio in Europe. In analyzing this impact, we modify the coefficient $\beta$ in equation (6) and (7) by adding a cross term, i.e. we estimate $\beta+\gamma Z$, where $Z$ measures either the minimum excise $(M I N)$, or country size $(S I Z E)$ or the tax gap (TAXGAP). If $\gamma$ appears to be significantly negative, this is an indication that variable $Z$ reduces the strategic responses of governments. If $\gamma$ turns out positive, variable $Z$ is accompanied by more aggressive tax competition.

\section{Regression results}

This section discusses our regression results. First, we present the estimates of (6) in a benchmark regression. Thereby, we show our results for both the fixed effects model and the model in first differences. Then, we explore alternative weighting matrices. Subsequently, we analyze how the intensity of tax competition is affected by the additional covariates: minimum excise, country size and tax gap.

\section{Do countries respond to each other's tax rates?}

Table 4.1 shows the regression results in a benchmark case. For the weighting matrix we assume that countries respond only to their neighbors, i.e. countries that share a common border, with uniform weights for these countries. The first two columns in table 4.1 show the coefficients for the fixed effects model, both without and with price variables. The last three columns show the same estimates in which we control for country fixed effect by the method of first differencing. Thereby, we use two-year lags for all variables. The final column excludes time fixed effects.

The table shows that the estimated coefficient for the tax interaction term is significantly positive in all specifications. The price variables exert a significant impact on the tax ratio. On the basis of the Wald-test statistic, we find that including price variables indeed gives the preferred specification compared to models excluding 
prices. This holds both for the fixed effects model and the first-difference model. ${ }^{16}$ We take the first-difference model as our preferred specification. The reason is that the fixed effects model suffers from potential unit root problems. Indeed, the error terms in the fixed effects model show a time trend for some of the countries in our sample. This may create spurious correlation. The first difference model does not suffer from this problem.

In the first-difference model, we see that indexation of excises is important as the price variable exerts a significant impact on the tax ratio. Moreover, as can be expected from the definition of the excise ratio, the diesel price has a statistically significant negative impact on the ratio. The minimum excise level exerts a positive impact but is only significant at the $10 \%$ level.

The strategic tax response in the first-difference model with price effects is 0.23 if we include time fixed effects. This suggests that a $10 \%$ increase in the excise ratio of neighboring countries will systematically increase a countries' own tax rate by between $2.3 \%$. This is consistent with the presence of tax competition in diesel excises. The strategic tax response is robust for alternative specifications. In the other columns of table 4.1, we find a significant strategic tax term, the magnitude of which moves between 0.17 (in the first-differences model without price variables) and 0.48 (the first-difference model without time fixed effects). Including time fixed effects appears to be important. Indeed, if we exclude time fixed effects from the regression, as in the final column of table 4.1, the strategic tax term increase from 0.23 to 0.48 . The neighbor's tax may thus capture common shocks that are correlated with the tax term. Ignoring time fixed effects may thus cause a bias in the estimates.

\footnotetext{
${ }^{16}$ The value of the Wald-test for including price variables is 70.26 for the fixed effects model and 17.53 for the model in first differences.
} 
Table 4.1 Fiscal reaction function estimates ${ }^{a}$

\begin{tabular}{|c|c|c|c|c|c|}
\hline & \multicolumn{2}{|c|}{ Fixed effects } & \multicolumn{3}{|c|}{ First differences } \\
\hline Neighbors' tax ratio & $\begin{array}{c}0.38^{* * *} \\
(3.12)\end{array}$ & $\begin{array}{l}0.32^{* * * *} \\
(3.97)\end{array}$ & $\begin{array}{l}0.17^{* *} \\
(2.04)\end{array}$ & $\begin{array}{l}0.23^{* * *} \\
(2.76)\end{array}$ & $\begin{array}{l}0.48^{* * * *} \\
(7.09)\end{array}$ \\
\hline ROAD & $\begin{array}{l}-0.04^{*} \\
(-1.92)\end{array}$ & $\begin{array}{c}-0.09^{* * *} \\
(-6.18)\end{array}$ & $\begin{array}{c}-0.02 \\
(-0.88)\end{array}$ & $\begin{array}{c}-0.03 \\
(-1.41) \\
\end{array}$ & $\begin{array}{c}-0.02 \\
(-1.09)\end{array}$ \\
\hline TRUCKSHARE & $\begin{array}{c}0.02 \\
(1.59)\end{array}$ & $\begin{array}{c}0.02^{* * * *} \\
(2.69)\end{array}$ & $\begin{array}{c}0.01^{*} \\
(1.92)\end{array}$ & $\begin{array}{c}0.01^{*} \\
(1.76)\end{array}$ & $\begin{array}{c}0.01 \\
(1.43)\end{array}$ \\
\hline DIESELCAP & $\begin{array}{c}0.04 \\
(0.72) \\
\end{array}$ & $\begin{array}{l}0.12^{* * * *} \\
(3.17)\end{array}$ & $\begin{array}{c}-0.07 \\
(-1.02) \\
\end{array}$ & $\begin{array}{c}-0.06 \\
(-0.90) \\
\end{array}$ & $\begin{array}{c}-0.07 \\
(-0.94) \\
\end{array}$ \\
\hline MIN & $\begin{array}{c}0.28 \\
(0.67)\end{array}$ & $\begin{array}{l}-0.50^{* *} \\
(-2.08)\end{array}$ & $\begin{array}{c}0.35^{* * *} \\
(3.78)\end{array}$ & $\begin{array}{c}0.20^{*} \\
(1.90)\end{array}$ & $\begin{array}{c}0.03 \\
(0.98)\end{array}$ \\
\hline PRICE & & $\begin{array}{l}0.46^{* * *} \\
(7.02)\end{array}$ & & $\begin{array}{l}0.33^{* * * *} \\
(3.02)\end{array}$ & $\begin{array}{l}0.42^{* * *} \\
(4.11)\end{array}$ \\
\hline DIESELPRICE & & $\begin{array}{c}0.10 \\
(0.64)\end{array}$ & & $\begin{array}{c}-0.42^{* * *} \\
(-3.62)\end{array}$ & $\begin{array}{c}-0.50^{* * *} \\
(-6.80)\end{array}$ \\
\hline $\mathrm{R}^{2}$ & 0.51 & 0.78 & 0.42 & 0.45 & 0.41 \\
\hline Country fixed effects & Yes & Yes & No & No & No \\
\hline Time fixed effects & Yes & Yes & Yes & Yes & No \\
\hline No. of observations & 374 & 374 & 340 & 340 & 340 \\
\hline No. of countries & 17 & 17 & 17 & 17 & 17 \\
\hline
\end{tabular}

${ }^{a * * *}$ denotes statistical significance at $1 \%$ level; ${ }^{* *}$ at $5 \%$ level; ${ }^{*}$ at $10 \%$ level. T-values in brackets

As a robustness check we experimented with alternative weighing matrices for the model in first-differences. In particular, our benchmark (first column of table 4.2) adopts the assumption that only neighboring countries exert an impact on a countries' tax and that all these neighbors feature a common impact. Table 4.2 shows the results of two alternative weights. In the second column of table 4.2, we present an estimate for the reaction function where the weights are determined by trade shares. In particular, we use the share of imports + export of a particular country in the total of imports + exports in all European countries as weights. Still, we assume here that only neighbors' taxes are relevant. In the third column, we not only include neighboring countries in the weighting matrix, but also other European countries that are located within a range of 1000 kilometers from a particular country, using the distances between capitals of countries as an indicator for location. Table 4.2 reveals that our results are not sensitive to these alternative specifications of the weighting matrix. 
Table 4.2 Fiscal reaction functions with alternative weighting matrices ${ }^{\text {a }}$

\begin{tabular}{|l|c|c|c|}
\hline & $\begin{array}{c}\text { Neighbors with } \\
\text { uniform shares }\end{array}$ & $\begin{array}{c}\text { Neighbors with } \\
\text { trade shares }\end{array}$ & $\begin{array}{c}\text { Countries within } \\
1000 \text { km circle }\end{array}$ \\
\hline Neighbors' tax ratio & $0.23^{* * * *}$ & $0.25^{* * *}$ & $0.23^{* * *}$ \\
& $(2.76)$ & $(2.96)$ & $-0.03)$ \\
\hline & -0.03 & -0.03 & $(-1.35)$ \\
\hline & $(-1.41)$ & $(-1.47)$ & $0.01^{*}$ \\
ROAD & $0.01^{*}$ & $0.01^{*}$ & $(1.72)$ \\
\hline & $(1.76)$ & $(1.69)$ & -0.06 \\
DIESELCAP & -0.06 & -0.06 & $(-0.88)$ \\
\hline & $(-0.90)$ & $(-0.87)$ & $(1.80)$ \\
MIN & $0.20^{*}$ & $0.18^{*}$ & $0.32^{* * *}$ \\
\hline & $(1.90)$ & $(1.72)$ & $(2.95)$ \\
\hline PRICE & $0.33^{* * *}$ & $0.33^{* * *}$ & $-0.43^{* * *}$ \\
\hline & $(3.02)$ & $(3.02)$ & $(-3.67)$ \\
\hline$R^{2}$ & $-0.42^{* * *}$ & $-0.42^{* * *}$ & 0.45 \\
\hline
\end{tabular}

${ }^{* * *}$ denotes statistical significance at the $1 \%$ level; ${ }^{* *}$ at the $5 \%$ level; ${ }^{*}$ at the $10 \%$ level. T-values are in brackets. The regressions refer to the model in first differences, including time fixed effects.

What determines the intensity of tax competition?

We now explore whether strategic tax responses depend on the harmonization policy imposed by the EU. In particular, we explore changes in our tax response variable by including (alternative specifications of) a cross-term in the regression. The first specification captures the minimum rate, i.e. it estimates a coefficient for Neighbor's $\operatorname{tax} *$ MIN. Subsequently, we analyze the cross-impact of a dummy for the year of harmonization 1987, and a time trend. The latter is used to explore whether strategic tax responses have significantly declined over time. Table 4.3 shows the results. 
Table 4.3 Fiscal reaction functions and the impact of the minimum rate ${ }^{\mathrm{a}}$

\begin{tabular}{|c|c|c|c|c|}
\hline & Base case & $\begin{array}{l}\text { Impact of the } \\
\text { minimum }\end{array}$ & $\begin{array}{c}\text { Impact of } \\
\text { harmonization }\end{array}$ & $\begin{array}{l}\text { Impact of time } \\
\text { trend }\end{array}$ \\
\hline Neighbors' tax ratio & $\begin{array}{l}0.23^{* * *} \\
(2.76)\end{array}$ & $\begin{array}{l}0.39^{* * *} \\
(3.17)\end{array}$ & $\begin{array}{l}0.40^{* * * *} \\
(3.20)\end{array}$ & $\begin{array}{l}0.41^{* * *} \\
(2.21)\end{array}$ \\
\hline Neighbor's tax * MIN & & $\begin{array}{l}-1.29^{*} \\
(-1.76)\end{array}$ & & \\
\hline Neighbor's tax * Dummy87 & & & $\begin{array}{l}-0.30^{*} \\
(-1.81) \\
\end{array}$ & \\
\hline Neighbor's tax * TIME & & & & $\begin{array}{l}-0.016 \\
(-1.08) \\
\end{array}$ \\
\hline ROAD & $\begin{array}{c}-0.03 \\
(-1.41)\end{array}$ & $\begin{array}{c}-0.03 \\
(-1.34)\end{array}$ & $\begin{array}{c}-0.03 \\
(-1.33)\end{array}$ & $\begin{array}{c}-0.03 \\
(-1.36)\end{array}$ \\
\hline TRUCKSHARE & $\begin{array}{l}0.01^{*} \\
(1.76)\end{array}$ & $\begin{array}{c}0.01 \\
(1.62)\end{array}$ & $\begin{array}{c}0.01 \\
(1.64)\end{array}$ & $\begin{array}{c}0.01^{*} \\
(1.70)\end{array}$ \\
\hline DIESELCAP & $\begin{array}{c}-0.06 \\
(-0.90)\end{array}$ & $\begin{array}{l}-0.06 \\
(-0.89)\end{array}$ & $\begin{array}{c}-0.06 \\
(-0.89)\end{array}$ & $\begin{array}{c}-0.06 \\
(-0.88)\end{array}$ \\
\hline $\mathrm{MIN}$ & $\begin{array}{c}0.20^{*} \\
(1.90)\end{array}$ & $\begin{array}{c}0.18^{*} \\
(1.65) \\
\end{array}$ & $\begin{array}{c}0.17 \\
(1.63) \\
\end{array}$ & $\begin{array}{c}0.19^{*} \\
(1.75) \\
\end{array}$ \\
\hline PRICE & $\begin{array}{l}0.33^{* * *} \\
(3.02)\end{array}$ & $\begin{array}{l}0.30^{* * * *} \\
(2.71)\end{array}$ & $\begin{array}{l}0.30^{* * *} \\
(2.73)\end{array}$ & $\begin{array}{l}0.31^{* * * *} \\
(2.79)\end{array}$ \\
\hline DIESELPRICE & $\begin{array}{l}-0.42^{* * * *} \\
(-3.62)\end{array}$ & $\begin{array}{l}-0.41^{* * * *} \\
(-3.53)\end{array}$ & $\begin{array}{l}-0.41^{* * * *} \\
(-3.49)\end{array}$ & $\begin{array}{l}-0.41^{* * *} \\
(-3.54)\end{array}$ \\
\hline $\mathrm{R}^{2}$ & 0.45 & 0.46 & 0.46 & 0.54 \\
\hline
\end{tabular}

${ }^{* * * *}$ denotes statistical significance at the $1 \%$ level $^{* *}$ at the $5 \%$ level; ${ }^{*}$ at the $10 \%$ level. T-values are in brackets.

The regressions refer to the model in first differences, including time fixed effects and price variables.

The results indicate that the minimum tax rate has reduced the intensity of tax competition in the form of strategic tax responses. Indeed, the estimates for the crossterms in table 4.3 are all negative. The specification with the dummy variable for 1987 is most easily interpreted: it suggests that the strategic tax interaction term falls from 0.40 for the pre-harmonization period (where Dummy 87 is zero) to 0.10 for the post-harmonization period (where the Dummy 87 is 1 ). ${ }^{17}$ This suggests that the minimum tax rate has reduced the intensity of tax competition to a considerable extent, although it has not disappeared entirely. However, the coefficients are not statistically significant at the $5 \%$ level in each of the three specifications (although it is significant at the $10 \%$ level in case of MIN or Dummy87). Hence, we cannot reject

\footnotetext{
${ }^{17}$ The model with the minimum rate instead of Dummy87 allows for more variation in the effect of the minimum excise level on the strategic interaction. Evaluated at the minimum rate that was imposed in 1992 of 0.245 , the strategic tax term for the post-harmonisation period is 0.08 (computed as $0.39-1.29$ * 0.245), compared to 0.39 for the pre-harmonisation period (where the minimum was zero). Evaluated at the mean value for the minimum over the entire sample period of 0.14 , we obtain an average coefficient for the entire sample period of 0,20 (computed as $0,39-1.29 * 0.14=0.20$ ). This is close the coefficient without the cross-term.
} 
the hypothesis that tax competition has maintained equally intense after the introduction of the minimum rate.

Finally, table 4.4 considers whether the strategic tax responses are affected by country size or the tax gap. In particular, we first include a cross-term in the regression which captures the impact of country size, measured by GDP, i.e.

Neighbor's tax * GDP. ${ }^{18}$ Next we include two alternative cross-terms capturing the impact of the tax gap. First, the tax gap is measured by a dummy variable, which is equal to one if a country features a tax rate above the median tax in the sample for a particular year and zero otherwise. Hence, we estimate the term Neighbor's tax * Dummy_hightax. Second, we measure the tax gap by the difference between a tax ratio and the median in the sample, i.e. Neighbor's tax * Tax_difference. The impact of the tax rate also follows from our theoretical model, where (3) allows for different tax responses of high-tax and low-tax countries.

Table 4.4 Fiscal reaction functions and the impact of size and the tax rate ${ }^{\mathrm{a}}$

\begin{tabular}{|c|c|c|c|c|}
\hline & Base case & $\begin{array}{c}\text { Impact of } \\
\text { Size }\end{array}$ & $\begin{array}{l}\text { Impact of } \\
\text { high_tax }\end{array}$ & $\begin{array}{c}\text { Impact of tax } \\
\text { difference }\end{array}$ \\
\hline Neighbors' tax ratio & $\begin{array}{l}0.23^{* * *} \\
(2.76)\end{array}$ & $\begin{array}{l}0.22^{* * *} \\
(2.56)\end{array}$ & $\begin{array}{l}0.23^{* *} \\
(2.50)\end{array}$ & $\begin{array}{l}0.22^{* * *} \\
(2.60)\end{array}$ \\
\hline Neighbor's tax * GDP & & $\begin{array}{l}0.002 \\
(0.33)\end{array}$ & & \\
\hline $\begin{array}{l}\text { Neighbor's tax * } \\
\text { Dummy_hightax }\end{array}$ & & & $\begin{array}{l}0.15^{*} \\
(1.66)\end{array}$ & \\
\hline $\begin{array}{l}\text { Neighbor's tax } * \\
\text { Tax_difference }\end{array}$ & & & & $\begin{array}{l}0.39^{* * *} \\
(3.36)\end{array}$ \\
\hline ROAD & $\begin{array}{c}-0.03 \\
(-1.41) \\
\end{array}$ & $\begin{array}{c}-0.03 \\
(-1.37)\end{array}$ & $\begin{array}{c}-0.02 \\
(-1.27)\end{array}$ & $\begin{array}{c}-0.02 \\
(-1.43)\end{array}$ \\
\hline TRUCKSHARE & $\begin{array}{l}0.01^{*} \\
(1.76) \\
\end{array}$ & $\begin{array}{l}0.01^{*} \\
(1.75) \\
\end{array}$ & $\begin{array}{c}0.01 \\
(1.52) \\
\end{array}$ & $\begin{array}{l}0.01^{*} \\
(1.65)\end{array}$ \\
\hline DIESELCAP & $\begin{array}{c}-0.06 \\
(-0.90)\end{array}$ & $\begin{array}{c}-0.06 \\
(-0.88)\end{array}$ & $\begin{array}{c}-0.05 \\
(-0.74)\end{array}$ & $\begin{array}{c}-0.06 \\
(-0.83)\end{array}$ \\
\hline MIN & $\begin{array}{l}0.20^{*} \\
(1.90)\end{array}$ & $\begin{array}{l}0.20^{*} \\
(1.88)\end{array}$ & $\begin{array}{l}0.17^{*} \\
(1.66)\end{array}$ & $\begin{array}{c}0.17 \\
(1.63) \\
\end{array}$ \\
\hline PRICE & $\begin{array}{l}0.33^{* * * *} \\
(3.02)\end{array}$ & $\begin{array}{l}0.33^{* * *} \\
(3.04)\end{array}$ & $\begin{array}{l}0.32^{* * *} \\
(2.89)\end{array}$ & $\begin{array}{l}0.34^{* * *} \\
(3.12) \\
\end{array}$ \\
\hline DIESELPRICE & $\begin{array}{l}-0.42^{* * *} \\
(-3.62)\end{array}$ & $\begin{array}{l}-0.42^{* * *} \\
(-3.54)\end{array}$ & $\begin{array}{l}-0.43^{* * *} \\
(-3.73)\end{array}$ & $\begin{array}{l}-0.45^{\text {*** }} \\
(-3.90)\end{array}$ \\
\hline $\mathrm{R}^{2}$ & 0.45 & 0.45 & 0.46 & 0.48 \\
\hline
\end{tabular}

${ }^{\text {a*** }}$ denotes statistical significance at the $1 \%$ level; $^{* *}$ at the $5 \%$ level; ${ }^{*}$ at the $10 \%$ level. T-values are in brackets. The regressions refer to the model in first differences, including time fixed effects and price variables.

\footnotetext{
${ }^{18}$ We also tried population and the number of trucks as indicators for size, but this does not change the results.
} 
The second column of table 4.4 reports a positive cross-term for Neighbor's tax * SIZE. This suggests that large countries respond more aggressively to their neighbor's tax rate than small countries do. The coefficient is not significant, however. Hence, we cannot reject the hypothesis that the strategic tax responses are equal between small and large countries.

The third and fourth columns in table 4.4 report a positive cross-term for Neighbor's tax *Dummy_hightax or Tax_difference. High-tax countries thus appear to respond more aggressively to the tax rate in their neighboring country than low-tax countries do. This result is similar to the findings reported by Devereux et al. (2001) regarding the relatively strong corporate tax response by high-tax countries compared to low-tax countries. In case of the dummy for high-tax countries, we obtain significance only at the $10 \%$ level. The coefficient suggests that the tax response of high-tax countries is 0.38 compared to only 0.23 for low-tax countries. With the size of the tax gap, as measured by the tax difference with the median tax ratio, the final column in table 4.4 reveals a significant impact even at the $1 \%$ level. The coefficient of 0.39 can be easily interpreted. To illustrate, if we evaluate the coefficient at a tax differential of 0.5 , i.e. for a country with a tax ratio that is $50 \%$ above the median level in the EU, the strategic tax response of that country equals 0.42 (i.e. $0.22+0.5 *$ $0.39)$, compared to 0.22 for a country at the median rate.

\section{Conclusion}

Following recent papers that empirically assess strategic interactions among countries with respect to corporate taxes, this paper estimates fiscal reaction functions for diesel excises in Europe. The estimates reveal that a 10\% higher tax rate in neighboring countries (in terms of the user price) induces a country to raise its own rate by around 2 to $3 \%$. This impact is robust for alternative specifications. This provides evidence for the presence of tax competition in diesel excises in Europe. We find evidence that the magnitude of the tax rate matters for the intensity of tax competition. In particular, high-tax countries compete more aggressively than low-tax tax countries. We find no evidence for the impact of country size on the intensity of tax competition.

Harmonization efforts of the EU have contributed to raise the average diesel excise in Europe and lead to convergence of rates. This suggests that the minimum excise rate has reduced the intensity of tax competition in the EU. Also the strategic 
tax interactions tend to decline in response to the minimum rate. Strategic tax responses do not disappear, however. Moreover, the impact of the minimum rate on the strategic tax responses is not statistically significant. Hence, we cannot reject the hypothesis that the minimum excise imposed since 1987 has not significantly reduced the intensity of tax competition as measured by the size of strategic tax interactions. This may yield an important lesson for other areas in which tax competition is important, such as corporate taxation. Indeed, imposing a minimum rate may be effective in avoiding a tax race to the bottom (which is often seen as harmful), while at the same time it maintains incentives for governments to compete and thus to tame the Leviathan. Hence, a minimum rate may strike an optimal balance between pros and cons of tax competition.

\section{References}

Altshuler, R. and T.J. Goodspeed, 2002, Follow the Leader? Evidence on European and U.S. Tax Competition, Rutgers University, Hunter College and CUNY Graduate Center, draft 19-07-2002

Besley, T., R. Griffith and A. Klemm, 2001, Fiscal Reaction Functions, mimeo, April.

Brueckner, J. K., 2002, Strategic Interaction Among Governments: An Overview of Empirical Studies, Institute of Government and Public Affairs University of Illinois at Urbana-Champaign

Bucovetski, S., 1991, Asymmetric Tax Competition, Journal of Urban Economics 30, 167-181.

Cnossen, S., 2002, Tax policy in the European Union: A review of issues and options, Finanzarchiv 58, 466-558.

Devereux, M.P., R. Griffith en A. Klemm, 2002a, Corporate Income Tax: Reforms and Tax Competition, Economic Policy, 451-495. 
Devereux, M., B. Lockwood and M. Redoano, 2002b, Do Countries Compete over Corporate Tax Rates?, CEPR Discussion Paper no. 3400.

Devereux, M., B. Lockwood and M. Redoano, 2004, Horizontal and Vertical Indirect Tax Competition: Theory and some Evidence from the USA, Warwick Economic Research Paper no. 704, University of Warwick.

Kanbur, R. and M. Keen, 1993, Jeux sans Frontieres: Tax Competition and Tax Coordination when Countries differ in Size, American Economic Review 83, 877-892.

Levinson, A., 2003, Environmental Regulatory Competition: A Status Report and some new Evidence, National Tax Journal LVI, 91-106.

Mooij, R.A. de, and S. Ederveen, 2003, Taxation and Foreign Direct Investment: A Synthesis of Empirical Results, International Tax and Public Finance 10, 673-693.

Wilson, J.D., 1999, Theories of Tax Competition, National Tax Journal 52, 269-304.

Zodrow, G.R., 2003, Tax Competition and Tax Coordination in the European Union, International Tax and Public Finance 10, 651-671. 


\section{Appendix: Minimum excises in ECU/Euro and development of excises}

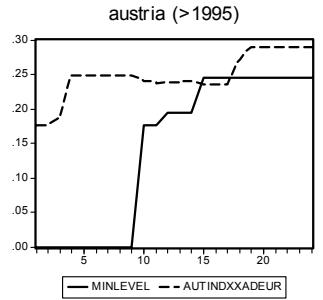

germany

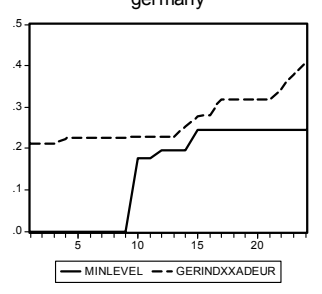

netherlands

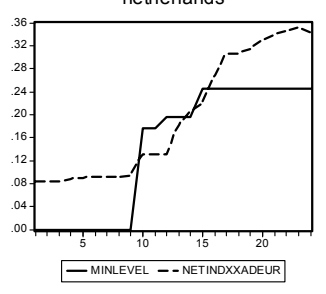

swi

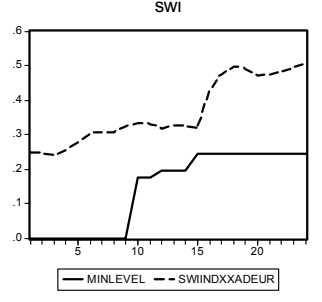

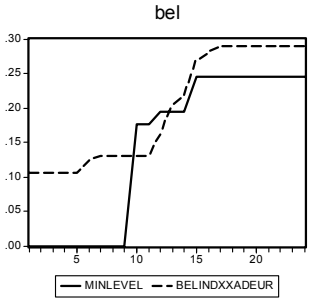

greece (>1981)

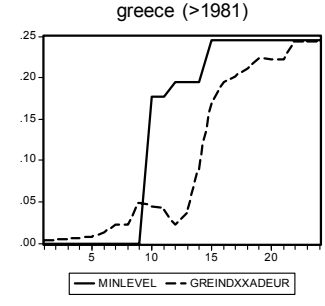

norway (not EU)

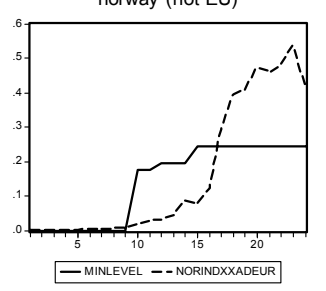

ukd

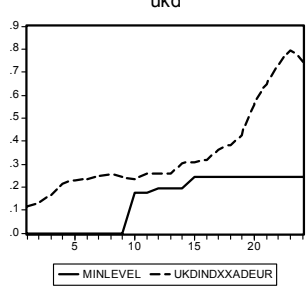

den
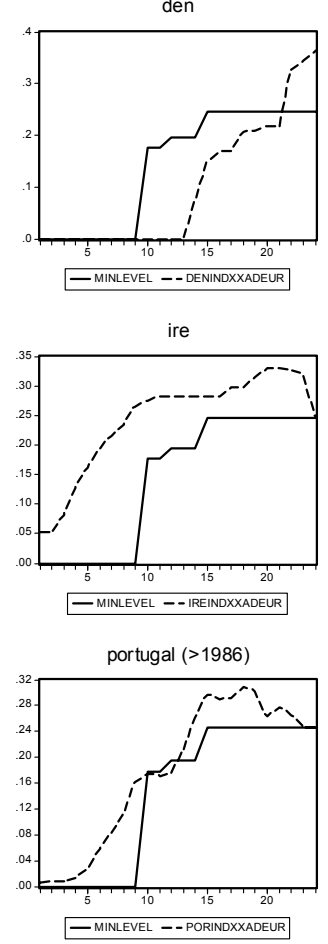

finland $(>1995)$
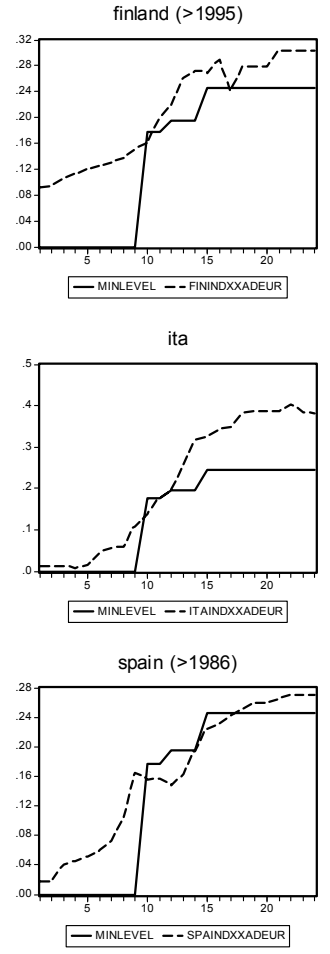

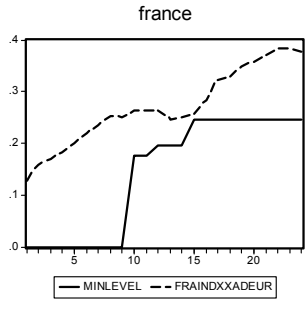

$\operatorname{lux}$

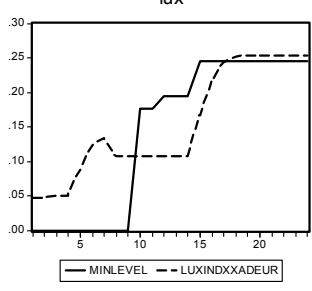

sweden (>1995)

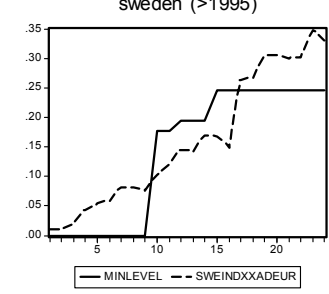

\section{Remarks:}

Excises after1999 in Euros for Euro-countries, data before 1999 local currencies converted with fixed 1999 Euro rate. Non Euro-countries loc.al currencies coverted to yearly average

\section{EU Excise directives}

Harmonized target level of excise duties was in 1987 ECU 0.177 per litre. Minimum levels of excise duties were raised to ECU 0.195 in 1989 and to ECU 0.245 in 1991. 